\title{
Cardiology
}

\section{Association of the $A G T$ Gene M235T (rs699) Polymorphism with Arterial Hypertension and Metabolic Risk Factors in the Indigenous People of Yakutia}

\author{
Sargylana I. Sofronova, $\mathrm{PhD}^{*}$; Maria P. Kirillina, $\mathrm{PhD}$; Irina V. Kononova, $\mathrm{PhD}$; \\ Anna N. Romanova, MD; Vyacheslav M. Nikolaev, PhD; Sardana K. Kononova, PhD \\ Yakut Science Center of Complex Medical Problems \\ Yakutsk, the Republic of Sakha (Yakutia), Russia
}

\begin{abstract}
The research objective was to study the association of the $A G T$ rs699 missense SNP with arterial hypertension (AH) and metabolic risk factors among indigenous people of the Arctic territory of Yakutia. The obtained data show that representatives of indigenous people of the Arctic territory of Yakutia with the homozygous GG genotype for the AGT SNP rs699 are characterized by high levels of systolic blood pressure. The carriage of the GG genotype in AH patients is associated with a high frequency of hypo-HDL cholesterolemia. The carriage of GG genotype in AH patients, compared to subjects without AH, is characterized by higher blood levels of total cholesterol, LDL-C, and triglycerides and is associated with a high frequency of abdominal obesity. Thus, the $A G T$ rs699 missense SNP was found to be associated with metabolic risk factors in indigenous AH persons of the Arctic territory of Yakutia. (International Journal of Biomedicine. 2019;9(4):287-291.)
\end{abstract}

Key Words: $A G T$ gene $\bullet$ polymorphism $\bullet$ arterial hypertension $\bullet$ risk factors $\bullet$ indigenous people $\bullet$ Yakutia

\section{Abbreviations}

AO, abdominal obesity; AH, arterial hypertension; BP, blood pressure; FPG, fasting plasma glucose; GWAS, Genome-wide association studies; HDL-C, high-density lipoprotein cholesterol; HP, hip circumference; HWE, Hardy-Weinberg equilibrium; LDL-C, low-density lipoprotein cholesterol; TC, total cholesterol; TG, triglycerides; RAS, renin-angiotensin system; SBP, systolic blood pressure; WC, waist circumference.

\section{Introduction}

Arterial hypertension $(\mathrm{AH})$ is the leading risk factor for disability and premature mortality in the global population. As of $2010,31.1 \%$ of the adult population of the world was suffering from hypertension $(30.7 \%$ of men and $28.8 \%$ of women). ${ }^{(1)}$ In Russia, according to an ESSE-RF epidemiological study, which was conducted in 12 regions, the prevalence of $\mathrm{AH}$ was $50.2 \%$ (51.1\% in men, $49.7 \%$ in women). ${ }^{(2)} \mathrm{AH}$ is

*Corresponding author: Sargylana I. Sofronova, PhD. Yakut Science Center of Complex Medical Problems. Yakutsk, the Republic of Sakha (Yakutia),Russia.E-mail:sara2208@mail.ru considered a multifactorial disease. From the early and negative GWAS for hypertension within the Wellcome Trust Case Control Consortium ${ }^{(3)}$ to the more recent reports, ${ }^{(4-6)} 10,280$ genetic variants have been associated with risk of high BP. The gene encoding angiotensinogen (AGT) has been implicated in hypertension both through genetic linkage studies and by allelic association. The $A G T$ rs 699 missense SNP is a $\mathrm{T}$ to $\mathrm{C}$ substitution in the exon 2, resulting in a functional methionine (M) to threonine (T) substitution at codon 268 (M268T). Previously, rs699 was positioned to the amino acid 235, and the SNP is therefore referred to as M235T. The rs699 threonine variant is associated with higher plasma AGT levels and higher BP. ${ }^{(7)}$ Despite numerous studies, the results are ambiguous and the degree and reliability of associations vary. 
The research objective was to study the association of the $A G T$ rs699 missense SNP with $\mathrm{AH}$ and metabolic risk factors among indigenous people of the Arctic territory of Yakutia.

\section{Materials and Methods}

Material was collected under expeditionary conditions in the Arctic territory of Yakutia, including places of compact residence of the indigenous peoples (Nizhnekolymsky, Verkhnekolymsky and Tomponsky districts). A total of 348 indigenous people of Yakutia were examined. The sample consisted of an adult population aged between 20 and 70 years (225 women and 123 men). All subjects were divided into 2 groups: the Case group consisted of 175 patients with $\mathrm{AH}$; the Control group included 173 people without elevated BP. The average age of hypertensive patients was $53.07 \pm 0.49$ years, those without $\mathrm{AH}-38.88 \pm 0.60$ years.

The research program included the following sections:

- Anthopometrical reference data: the measurements of BMI $\left(\mathrm{kg} / \mathrm{cm}^{2}\right), \mathrm{WC}(\mathrm{cm})$ and $\mathrm{HC}(\mathrm{cm})$

- Assessment of BP by Korotkov's method. BP was measured twice with an OMRON automatic tonometer (Japan) on the right hand in a sitting position with the calculation of the average BP

- Assessment of FPG, OGTT, and blood levels of TC, TG, HDL-C, and LDL-C

Glucose and lipid metabolism disorders were diagnosed according to the Russian national recommendations (the AllRussian Scientific Society of Cardiologists [VNOK, 2009]) ${ }^{(8)}$ based on the IDF consensus criteria $(2006)^{(9):} \mathrm{TG} \geq 1.7 \mathrm{mmol} / \mathrm{l}$; HDL-C $<1.0 \mathrm{mmol} / 1$ in males and $<1.2 \mathrm{mmol} / 1$ in females; LDL-C $>3.0 \mathrm{mmol} / \mathrm{l} ; \mathrm{FPG}>6.1 \mathrm{mmol} / \mathrm{l}$; IGT $2 \mathrm{Hr}$ PG $\geq 7.8 \mathrm{mmol} / 1$ and $\leq 11 \mathrm{mmol} / \mathrm{l}$. Abdominal obesity $(\mathrm{AO})$ was confirmed at $\mathrm{WC} \geq$ $94 \mathrm{~cm}$ in males and $\geq 80 \mathrm{~cm}$ in females.

The diagnosis of AH was based on 2017 ACC/AHA Guideline for or the Prevention, Detection, Evaluation, and Management of High Blood Pressure in Adults. ${ }^{(10)}$

Genotyping of the AGT rs699 missense SNP was performed in the laboratory of molecular genetics at YSC CMP. From each patient, $2 \mathrm{~mL}$ of peripheral blood were drawn into an EDTA tube. Genomic DNA was isolated from the peripheral blood leukocytes using standard phenolchloroform extraction technique. Allelic variants of the AGT rs699 missense SNP were tested by real-time PCR on the «Real-time CFX96» amplifier (BioRad, USA) using Lytech kits (Lytech R\&D LLC, Moscow) in accordance with the manufacturer's instructions. The actual SNP for M235T is a $\mathrm{T} \rightarrow \mathrm{C}$ substitution; however, the pyrosequencing was done by using the reverse complement strand, which resulted in an allele call of $\mathrm{A} \rightarrow \mathrm{G}$. For quality control, $10 \%$ of samples were randomly repeated, with complete congruence.

The study was approved by the Ethics Committee of the Yakut Science Center of Complex Medical Problems. Written informed consent was obtained from each patient.

Statistical analysis was performed using SPSS (version 19.0). Baseline characteristics were summarized as frequencies and percentages for categorical variables and as mean \pm SEM for continuous variables. Means of 2 continuous normally distributed variables were compared by independent samples Student's t test. Mann-Whitney U test was used to compare means of 2 groups of variables not normally distributed. Odds ratios (ORs) and 95\% confidence intervals (CIs) were calculated. Deviation from Hardy-Weinberg equilibrium and differences in allele distributions between the two groups were assessed by $\chi 2$ - test with 1 degree of freedom (df). A probability value of $P<0.05$ was considered statistically significant.

\section{Results and Discussion}

In the general population, the frequencies of the AA, AG and GG genotypes of the AGT rs699 SNP were $15.5 \%(n=54)$, $45.1 \%(\mathrm{n}=157)$, and $39.4 \%(\mathrm{n}=137)$, respectively, which corresponds to the HWE; the frequencies of the A allele and $\mathrm{G}$ allele were $38.1 \%(n=265)$ and $61.9 \%(n=431)$ (Table 1$)$.

\section{Table 1.}

Frequencies of genotypes and alleles of the M235T polymorphism of the AGT gene and correspondence to Hardy-Weinberg equilibrium (HWE)

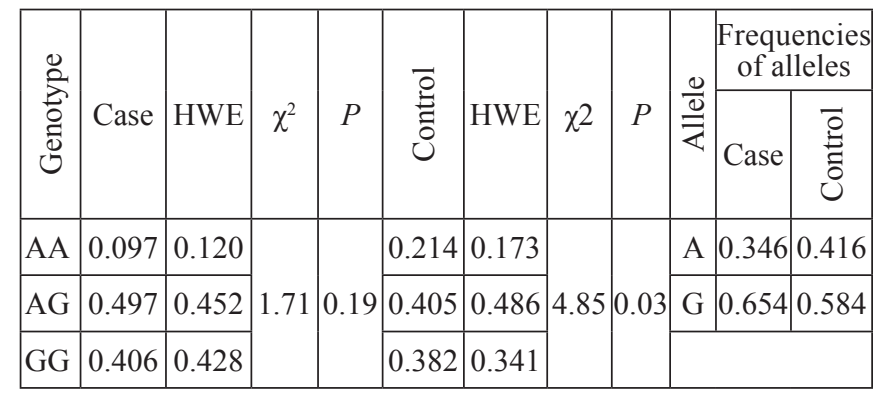

In the general population, we found significant differences in average values of TC, LDL-C, and TG, depending on the carriage of genotypes of the AGT rs699 SNP. Thus, in carriers of the GG homozygous genotype, all values were higher than in AG heterozygotes and AA homozygotes. On the contrary, the average FPG level was significantly lower in GG carriers than in AG carriers and AA carriers. Carriers of all genotypes showed a high frequency of hypercholesterolemia, hyperLDL cholesterolemia and hypo-HDL cholesterolemia without significant differences between genotypes. Thus, in the general population, the average frequency of hypercholesterolemia, hyper-LDL cholesterolemia, and hypo-HDL cholesterolemia was $45.8 \%, 63.3 \%$, and $35.4 \%$, respectively. The frequency of hypertriglyceridemia was as follows: AA carriers - 5.5\% and GG carriers - $17.5 \%(P=0.033)$. The frequency of an increased FPG level was significantly higher in AG heterozygotes than in individuals with the mutant GG genotype $(8.3 \%$ and $2.9 \%$, respectively, $P=0.048$ ). In the general population, the frequency of AO in GG carriers, AG carriers and AA carriers was as follows: $60.6 \%, 59.2 \%$, and $46.3 \%$, respectively $(P=0.174)$.

Considering the high frequency of $\mathrm{AH}$ in the general population $(53.3 \%)$, we conducted a case-control study that included $175 \mathrm{AH}$ persons (Case group) and 173 normotensive 
persons (Control group) to determine the association of the $A G T$ rs699 SNP with hypertension and metabolic risk factors among indigenous people of the Arctic territory of Yakutia.

We did not find statistically significant differences in the frequency distribution of the $\mathrm{AG}$ and $\mathrm{GG}$ genotypes between the Case group and the Control group. The frequency of the AA genotype was lower in the Case group than in the Control group: $9.7 \%$ and $21.4 \%(P=0.009)$. The distribution of the genotype frequency was not in HWE for the Control group $(\chi 2=4.85$, $P=0.03$ ) (Table 1). The occurrence of the departure from HWE in controls is probably due to population substructure.

We further used the two types of genetic models (Dominant and Recessive models of inheritance) to test the association between the $A G T$ rs699 SNP and AH; the results are shown in Tables 2 and 3. We found a link between AH and the mutant homozygous GG genotype and the heterozygous AG genotype in the dominant model $(\mathrm{OR}=2.53,95 \% \mathrm{CI}=1.36$ 4.69, $P=0.003$ ). A number of studies have also found an association of the $\mathrm{G}$ allele and the GG genotype with the risk for developing hypertension. ${ }^{(11-16)}$ The Russian study, which included 514 patients, found an association of the $\mathrm{G}$ allele with the risk for developing hypertension in men, with an odds ratio of $1.95(P=0.003) .{ }^{(17)}$ However, a number of studies did not find a reliable association of $\mathrm{AG}$ and $\mathrm{GG}$ genotypes with $\mathrm{AH} .{ }^{(18-22)}$

Table 2.

Dominant model of inheritance $(d f=1)$

\begin{tabular}{|l|c|c|c|c|c|c|}
\hline \multirow{2}{*}{ Genotype } & \multicolumn{2}{|c|}{$\begin{array}{c}\text { Genotype } \\
\text { frequencies }\end{array}$} & \multirow{2}{*}{$\chi^{2}$} & \multirow{2}{*}{$P$} & OR & $95 \% \mathrm{CI}$ \\
\cline { 2 - 3 } & $\begin{array}{c}\text { Case } \\
(\mathrm{n}=175)\end{array}$ & $\begin{array}{c}\text { Control } \\
(\mathrm{n}=173)\end{array}$ & & & & \\
\hline $\mathrm{AG}+\mathrm{GG}$ & 0.903 & 0.786 & \multirow{2}{*}{9.04} & 0.003 & 2.53 & $1.36-4.69$ \\
\hline AA & 0.097 & 0.214 & & 0.40 & $0.21-0.73$ \\
\hline
\end{tabular}

Table 3.

Recessive model of inheritance $(d f=1)$

\begin{tabular}{|l|c|c|c|c|c|c|}
\hline \multirow{2}{*}{ Genotype } & \multicolumn{2}{|c|}{$\begin{array}{c}\text { Genotype } \\
\text { frequencies }\end{array}$} & \multirow{2}{*}{$\chi^{2}$} & \multirow{2}{*}{$P$} & OR & \multirow{2}{*}{$95 \% \mathrm{CI}$} \\
\cline { 2 - 3 } & $\begin{array}{c}\text { Case } \\
(\mathrm{n}=175)\end{array}$ & $\begin{array}{c}\text { Control } \\
(\mathrm{n}=173)\end{array}$ & & & & \\
\hline $\mathrm{GG}$ & 0.406 & 0.382 & \multirow{2}{*}{0.21} & \multirow{2}{*}{0.64} & 1.11 & $0.72-1.70$ \\
\cline { 1 - 3 } & 0.594 & 0.618 & & & 0.90 & $0.59-1.39$ \\
\hline
\end{tabular}
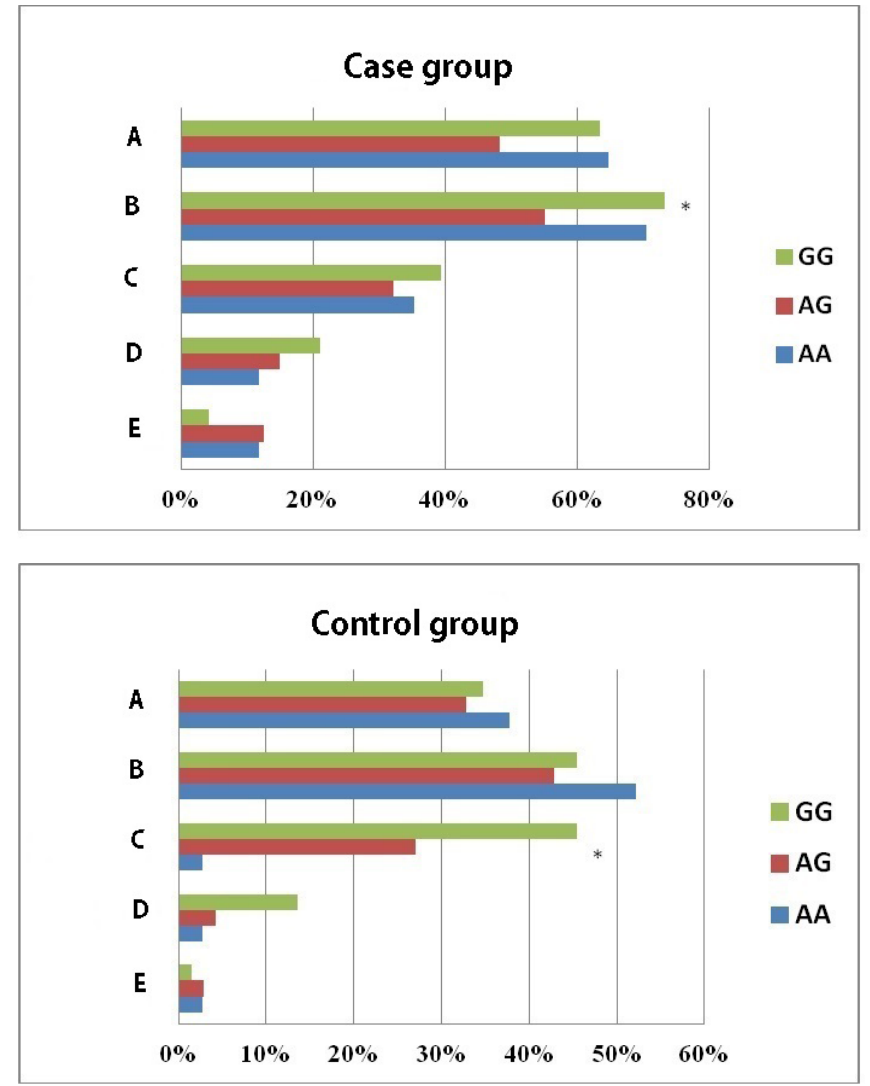

Figure 1. The frequency of dyslipidemia and carbohydrate metabolism in individuals with and without AH, depending on the carriage of genotypes of the AGT rs699 SNP.

A-hypercholesterolemia; B-hyper-LDL cholesterolemia; C-hypoHDL cholesterolemia; D-hypertriglyceridemia; E-increased FPG level; *- $P<0.05$

In Group 1 patients with $\mathrm{AH}$, the average level of SBP in carriers of AA, AG and GG genotypes was $159.72 \pm 1.92 \mathrm{mmHg}$, $161.72 \pm 1.40 \mathrm{mmHg}$ and $173.53 \pm 3.62 \mathrm{mmHg}$, respectively ( $\mathrm{F}=6.6763, P=0.0016$ ).

Table 4 presents the relationship between $A G T$ genotype carriage and parameters of lipid and glucose metabolism in patients with and without $\mathrm{AH}$. The $\mathrm{TG}$ level was significantly higher in the Case group regardless of the genotype carriage. In GG carriers, the blood levels of TC and LDL-C were significantly higher in the Case group than in the Control group. The AG carriers in the Case group had significantly lower HDL-C values than in the Control group. In AA and AG carriers, the FPG level was significantly higher in the Case group than in the Control group.

Table 4.

Mean levels of the parameters of lipid spectrum and blood glucose in indigenous people with and without AH depending on carriage of genotypes of the AGT rs699 SNP

\begin{tabular}{|l|c|c|c|c|c|c|c|c|c|}
\hline \multirow{2}{*}{$\begin{array}{c}\text { Blood } \\
\text { parameters }\end{array}$} & \multicolumn{3}{|c|}{ AA genotype } & \multicolumn{3}{c|}{ AG genotype } & \multicolumn{3}{c|}{ GG genotype } \\
\cline { 2 - 9 } & Case & $P$ & Control & Case & $P$ & Control & Case & $P$ & Control \\
\hline TC & $5.16 \pm 0.11$ & $<0.05$ & $4.74 \pm 0.16$ & $4.98 \pm 0.08$ & $>0.05$ & $4.78 \pm 0.10$ & $5.29 \pm 0.07$ & $<0.01$ & $4.74 \pm 0.09$ \\
\hline LDL-C & $3.30 \pm 0.08$ & $>0.05$ & $3.06 \pm 0.12$ & $3.17 \pm 0.06$ & $>0.05$ & $2.98 \pm 0.08$ & $3.47 \pm 0.06$ & $<0.01$ & $3.04 \pm 0.08$ \\
\hline HDL-C & $1.32 \pm 0.06$ & $>0.05$ & $1.26 \pm 0.05$ & $1.29 \pm 0.02$ & $<0.05$ & $1.40 \pm 0.04$ & $1.22 \pm 0.02$ & $>0.05$ & $1.23 \pm 0.03$ \\
\hline TG & $1.17 \pm 0.08$ & $<0.02$ & $0.90 \pm 0.06$ & $1.14 \pm 0.03$ & $<0.01$ & $0.87 \pm 0.04$ & $1.29 \pm 0.05$ & $<0.05$ & $1.05 \pm 0.06$ \\
\hline FPG & $5.37 \pm 0.24$ & $<0.01$ & $4.43 \pm 0.14$ & $5.10 \pm 0.15$ & $<0.01$ & $4.15 \pm 0.10$ & $4.40 \pm 0.10$ & $>0.05$ & $4.24 \pm 0.10$ \\
\hline
\end{tabular}


In the Case and Control groups, we found a significantly higher incidence of hypo-HDL cholesterolemia in GG carriers than in carriers of the AA and AG genotypes (Fig. 1). It should be noted that only a few studies confirm the association of the $\mathrm{G}$ allele with the presence of hypercholesterolemia. ${ }^{(23)}$

In the Case group, the highest incidence of $\mathrm{AO}$ was found in carriers of the AG and GG genotypes (76.1\% and 83.9\%). In the Control group, the frequency of $\mathrm{AO}$ varied from $28.6 \%$ in $\mathrm{AG}$ carriers to $43.9 \%$ in GG carriers. It should be noted that a contribution of the GG genotype to the development of metabolic syndrome was confirmed by a number of studies..$^{(24,25)}$

\section{Conclusion}

The obtained data show that representatives of indigenous people of the Arctic territory of Yakutia with the homozygous GG genotype for the $A G T$ SNP rs699 are characterized by high levels of SBD. The carriage of the GG genotype in AH patients is associated with a high frequency of hypo-HDL cholesterolemia. The carriage of GG genotype in AH patients, compared to subjects without $\mathrm{AH}$, is characterized by higher blood levels of TC, LDL-C, and TG and is associated with a high frequency of AO. Thus, the $A G T$ rs699 missense SNP was found to be associated with metabolic risk factors in indigenous AH persons of the Arctic territory of Yakutia.

\section{Competing Interests} interests.

The authors declare that they have no competing

\section{Sources of Funding}

The study was carried out within the framework of the project "Contribution of metabolic syndrome to the development of coronary artery atherosclerosis in residents of Yakutia" and R\&D "Development of new technologies for the treatment and risk prediction of hypertension and stroke in the Republic of Sakha (Yakutia)" (State Contract No. 1133).

\section{References}

1. Mills KT, Bundy JD, Kelly TN, Reed JE, Kearney PM, ReynoldsK, etal.GlobalDisparities of HypertensionPrevalence and Control: A Systematic Analysis of Population-Based Studies From 90 Countries. Circulation. 2016;134(6):441-50. doi: 10.1161/CIRCULATIONAHA.115.018912.

2. Erina AM, Rotar OP, Solntsev VN, Shalnova SA, Deev AD, Baranova EI, et al. [Epidemiology of Arterial Hypertension in Russian Federation - Importance of Choice of Criteria of Diagnosis].Kardiologiia. 2019;59(6):5-11. doi: 10.18087/cardio.2019.6.2595. [Article in Russian]

3. Wellcome Trust Case Control Consortium. Genome-wide association study of 14,000 cases of seven common diseases and 3,000 shared controls. Nature. 2007;447(7145):661-78.

4. Ehret GB, Ferreira T, Chasman DI, Jackson AU, Schmidt EM, Johnson T, et al. The genetics of blood pressure regulation and its target organs from association studies in 342,415 individuals. Nat Genet. 2016 Oct;48(10):1171-1184. doi: $10.1038 /$ ng.3667.

5. Warren HR, Evangelou E, Cabrera CP, Gao H, Ren M, Mifsud B, et al. Genome-wide association analysis identifies novel blood pressure loci and offers biological insights into cardiovascular risk. Nat Genet 2017;49(3):403-415. doi: 10.1038/ng.3768.

6. Hoffmann TJ, Ehret GB, Nandakumar P, Ranatunga D, Schaefer C, Kwok PY, et al. Genome-wide association analyses using electronic health records identify new loci influencing blood pressure variation. Nat Genet. 2017;49(1):54-64. doi: 10.1038/ng.3715.

7. Sethi AA, Nordestgaard BG, Tybjaerg-Hansen A. Angiotensinogen gene polymorphism, plasma angiotensinogen, and risk of hypertension and ischemic heart disease: a meta-analysis. Arterioscler Thromb Vasc Biol. 2003;23(7):1269-75.

8. Metabolic syndrome diagnostics and treatment. Compilation of national recommendations. Moscow: SiliceaPoligraf Publishers; 2009:106-143. [In Russian].

9. IDF Consensus Worldwide Definition of the Metabolic Syndrome, 2006. Available from: https://www.idf.org/elibrary/consensus-statements/60-idfconsensus-worldwidedefinitionof-the-metabolic-syndrome

10. Whelton PK, Carey RM, Aronow WS, Casey DE Jr, Collins KJ, Dennison Himmelfarb C, et al. 2017 ACC/AHA/ AAPA/ABC/ACPM/AGS/APhA/ASH/ASPC/NMA/PCNA Guideline for the Prevention, Detection, Evaluation, and Management of High Blood Pressure in Adults: A Report of the American College of Cardiology/American Heart Association Task Force on Clinical Practice Guidelines. J Am Coll Cardiol. 2018;71(19):e127-e248. doi: 10.1016/j.jacc.2017.11.006.

11. Fang YJ, Deng HB, Thomas GN, Tzang CH, Li CX, Xu $\mathrm{ZL}$, et al. Linkage of angiotensinogen gene polymorphisms with hypertension in a sibling study of Hong Kong Chinese. J Hypertens. 2010;28(6):1203-9. doi: 10.1097/ HJH.0b013e3283384b07.

12. Gopi Chand M, Srinath J, Rao RS, Lakkakula BV, Kumar S, Rao VR. Association between the M268T polymorphism in the angiotensinogen gene and essential hypertension in a South Indian population. Biochem Genet. 2011;49(7-8):47482. doi: 10.1007/s10528-011-9423-y.

13. Ji LD, Zhang LN, Shen P, Wang P, Zhang YM, Xing $\mathrm{WH}, \mathrm{Xu}$ J. Association of angiotensinogen gene M235T and angiotensin-converting enzyme gene $\mathrm{I} / \mathrm{D}$ polymorphisms with essential hypertension in Han Chinese population: a meta-analysis. J Hypertens. 2010;28(3):419-28. doi: 10.1097/ HJH.0b013e32833456b9.

14. Kurbanova D, Eliseyeva M. Genetic background of left ventricular hypertrophy in Uzbek hypertensive men. Turk Kardiyol Dern Ars. 2010;38(7):466-72.

15. Say YH, Ling KH, Duraisamy G, Isaac S, Rosli R. Angiotensinogen M235T gene variants and its association with essential hypertension and plasma renin activity in Malaysian subjects: a case control study. BMC Cardiovasc Disord. 2005;5(1):7.

16. Shamaa MM, Fouad H, Haroun M. et al. Association between the Angiotensinogen (AGT) gene (M235T) polymorphism and Essential Hypertension in Egyptian patients. The Egyptian Heart Journal. 2015; 67(1):1-5. doi: 10.1016/j.ehj.2013.10.001

17. Maximov VN, Orlov PS, Malyutina SK, Mazdorova EV, Nikitin YuP, Voevoda MIAssociation of genetic markers in hypertensive disease in the Siberian population. Russian 
Journal of Cardiology. 2014;(10):73-76.

18. Bautista LE, Vargas CI, Oróstegui M, Gamarra G. Population-based case-control study of renin-angiotensin system genes polymorphisms and hypertension among Hispanics. Hypertens Res. 2008;31(3):401-8. doi: 10.1291/ hypres.31.401

19. Glavnik N, Petrovic D. M235T polymorphism of the angiotensinogen gene and insertion/deletion polymorphism of the angiotensin-1 converting enzyme gene in essential arterial hypertension in Caucasians. Folia Biol (Praha). 2007;53:69-70. 20. Mohana VU, Swapna N, Surender RS, Vishnupriya S, Padma T. Gender-related association of AGT gene variants (M235T and T174M) with essential hypertension--a casecontrol study. Clin Exp Hypertens. 2012;34(1):38-44. doi: 10.3109/10641963.2011.618207.

21. Saab YB, Gard PR, Overall ADJ. The association of hypertension with renin-angiotensin system gene polymorphisms in the Lebanese population. J Renin Angiotensin Aldosterone Syst. 2011;12(4):588-94. doi: $10.1177 / 1470320311408465$.
22. Ying CQ, Wang YH, Wu ZL, Fang MW, Wang J, Li YS, et al. Association of the renin gene polymorphism, three angiotensinogen gene polymorphisms and the haplotypes with essential hypertension in the Mongolian population. Clin Exp Hypertens. 2010;32(5):293-300. doi: 10.3109/10641960903443517.

23. Niemiec P, Zak I, Wita K. The M235T polymorphism of the AGT gene modifies the risk of coronary artery disease associated with the presence of hypercholesterolemia. Eur J Epidemiol. 2008;23(5):349-54. doi: 10.1007/s10654-0089241-7.

24. Procopciuc LM, Sitar-Tăut A, Pop D, Sitar-Tăut DA, Olteanu I, Zdrenghea D. Renin angiotensin system polymorphisms in patients with metabolic syndrome (MetS). Eur J Intern Med. 2010;21(5):414-8. doi: 10.1016/j. ejim.2010.06.001.

25. Takakura Y, Yoshida T, Yoshioka K, Umekawa T, Kogure A, Toda H, et al. Angiotensinogen gene polymorphism (Met235Thr) influences visceral obesity and insulin resistance in obese Japanese women.Metabolism. 2006;55(6):819-24. 